\title{
La protección de datos personales de niños, niñas y adolescentes: respuestas desde el ordenamiento jurídico chileno
}

\author{
The Protection of Personal Data of Children and Adolescents: Answers from \\ the Chilean Legal Order
}

\author{
Isaac RAVETLLAT BALLESTÉ $\mathbf{1}$ \\ Constanza BASOALTO RIVEROS 2
}

\begin{abstract}
Resumen: En la actualidad, el tratamiento de los datos personales de niños, niñas y adolescentes por parte de terceros, singularmente las empresas, se ha convertido en un tema de crucial importancia en la medida que, cada vez más, éstas les dirigen bienes y servicios de índole virtual. En este sentido, y debido a la particular naturaleza jurídica como derecho de la personalidad, atribuida al derecho a la protección de datos personales, la fijación del límite de edad para poder disponer libremente de la información personal se erige como una cuestión clave, puesto que de ello dependerá, a efectos prácticos, la necesidad o no de recabar la llamada autorización parental. El silencio que tradicionalmente ha mantenido la legislación civil chilena en este ámbito material se traduce, además de en altas dosis de inseguridad jurídica, en una visión del niño, niña y adolescente como un sujeto incapaz, poco autónomo y absolutamente vulnerable frente a las nuevas tecnologías, visión ésta que amerita de una urgente e inmediata revisión.
\end{abstract}

Palabras clave: Protección de datos personales, infancia y adolescencia, consentimiento

\begin{abstract}
Currently, the treatment of the personal data of children and adolescents by third parties, particularly companies, has become a matter of crucial importance as, increasingly, they

\footnotetext{
${ }^{1}$ Profesor Asistente de la Facultad de Ciencias Jurídicas y Sociales de la Universidad de Talca. Doctor y Magíster en Derecho de Familia e Infancia por la Universidad de Barcelona (España). Director del Centro de Estudios sobre los Derechos de la Infancia y la Adolescencia de la Universidad de Talca. Subcoordinador general de la Red de Universidades por la Infancia. Vocal del Observa torio de la Infancia de la Generalitat de Cataluña (España), ciudad de Talca, Chile. Correo electrónico: iravetllat@utalca.cl

2 Profesora instructora de la Facultad de Ciencias Jurídicas de la Universidad Santo Tomás. Abogada, Licenciada en Ciencias Jurídicas y Sociales de la Universidad de Talca. Magíster en Derecho, con mención en Derecho de Familia de la Universidad de Talca, ciudad de Talca, Chile. Correo electrónico: cbasoalto3@santotomas.cl
} 
direct goods and services to them. virtual nature. In this sense, and due to the particular legal nature as a personality right, attributed to the right to the protection of personal data, the setting of the age limit to freely dispose of personal information stands as a key issue, since the practicality or not of obtaining the so-called parental authorization will depend on it. In addition to high doses of legal uncertainty, the silence that Chilean civil legislation has traditionally maintained in this material sphere translates into a vision of the child and adolescent as an incapable subject, not very autonomous and absolutely vulnerable to new technologies. This is a vision that warrants an urgent and immediate review.

Keywords: Protection of Personal Data, Childhood and Adolescence, Consent

\section{Introducción}

El presente artículo pretende llevar a cabo un análisis pormenorizado de las principales previsiones contenidas en la normativa chilena relativas al régimen jurídico aplicable al derecho a la protección de datos personales, específicamente cuando su titularidad y ejercicio corresponden a un individuo que todavía no ha alcanzado la mayoría de edad. Para ello, principiamos nuestra investigación con un examen exhaustivo del referido derecho fundamental ${ }^{3}$, pues únicamente conociendo su origen, naturaleza y ámbito de extensión estaremos en predisposición de abordar, con garantías, su estudio desde la perspectiva de los derechos de la infancia y la adolescencia. Así, una vez efectuadas estas reflexiones de cohorte más general, el texto prosigue con una revisión minuciosa de las múltiples controversias legales que suscita la presencia activa de personas menores de edad en el entorno audiovisual, no tanto por lo que a la titularidad de sus derechos se refiere, sino más bien en todo lo relativo a su ejercicio efectivo, así como a determinar cuáles son las salvaguardas legales previstas para garantizar la veracidad del consentimiento digital prestado por el usuario menor de edad, o en su defecto, por sus representantes legales ${ }^{4}$. Para alcanzar los objetivos propuestos en nuestro

\footnotetext{
${ }^{3}$ Parte de la doctrina se cuestiona la utilización unívoca de las nociones de derechos fundamentales y de derechos de la personalidad. En este sentido, Rogel (1985), pp. 76-77, nos recuerda que ni los autores ni los textos legales utilizan de modo unívoco los términos derechos humanos, derechos naturales, derechos fundamentales, derechos subjetivos, libertades públicas y derechos de la personalidad, y de hecho, la distinción no es clara. Asimismo, Aguilar (2010), pp. 15-57, nos plantea la concurrencia y divergencia - real o aparente - entre derechos fundamentales y derechos humanos. Por su parte, López (1986), p. 1113, apunta que sólo algunos derechos de la personalidad se plasman como derechos fundamentales. La consecuencia práctica más importante de calificarlos o no como derechos fundamentales es, entonces, la garantía constitucional especial de los constitucionalmente consagrados. También Guzmán (2006), pp. 55-56, se pronuncia sobre la cuestión, al apuntar que el hecho de ser persona es el título que hace sinónimas las expresiones derechos humanos, de la personalidad y extrapatrimoniales. Por último, también analiza el tema Aillapán (2016), pp. 435-462, quien concluye que, en el estado actual de la dogmática chilena, es posible deslindar las categorías "derechos de la personalidad" y "derechos fundamentales", correspondiéndose la primera con el Derecho Civil y la segunda con el Derecho Constitucional.

${ }^{4}$ Godoy (2018), p. 12. Asimismo, Arén (2017), p. 56, defiende la idea de que hay que promover una ciudadanía digital entre niños, niñas y adolescentes, haciéndoles tomar conciencia sobre lo que significa la intimidad, la privacidad y la protección de los derechos y deberes. Por su parte, Villanueva (2017), p. 213, señala que las personas menores de edad son indiscutiblemente titulares del derecho a la protección de datos personales. Finalmente, Brito (2018), p. 4, afirma que no existe una diferencia tajante entre las necesidades de protección y las necesidades relacionadas con la autonomía del sujeto, estableciendo que la mejor forma de garantizar social y jurídicamente la protección de la infancia es promover su autonomía como sujetos.
} 
estudio nos será de gran utilidad una aproximación a las previsiones contenidas tanto en el Reglamento General de la Unión Europea 2016/679, relativo a la Protección de Datos, como a la Ley Orgánica 3/2018, de 5 de diciembre, de Protección de Datos Personales y Garantía de los Derechos Digitales, que regula dicha realidad en España, por representar ambos textos normativos un antecedente digno de ser tomado en consideración de cara a una posible modernización del marco jurídico vigente en el Estado chileno.

\section{El derecho a la protección de datos personales: origen, naturaleza y ámbito de protección}

\subsection{ORÍGENES Y AUTONOMÍA JURÍDICA}

El acercamiento al estudio de cualquier derecho con rango constitucional requiere, sin duda, de una referencia a sus orígenes, para lo cual, en esta ocasión nos será de gran utilidad la clasificación generacional de los derechos humanos elaborada a nivel doctrinal 5 .

En general, históricamente ha prevalecido el reconocimiento de cuatro generaciones de derechos fundamentales, —derechos individuales o de primera generación; libertades públicas o derechos de segunda generación; derechos sociales o de tercera generación; y derechos vinculados con la irrupción de las nuevas tecnologías y el desarrollo científico, encasillados en la cuarta generación 6 -, estos han correspondido a momentos ideológicos y sociales con características propias y rasgos diferenciadores. En particular, la cuarta generación se presenta como una respuesta al fenómeno conocido como "contaminación de libertades"7, _liberties

\footnotetext{
${ }^{5}$ Conforme señala Pizzorusso (2002), pp. 493 y ss., doctrinariamente se habla de generaciones de derechos para catalogarlos atendiendo a su contenido normativo y evolución histórica. El primero en formular esta clasificación fue el profesor y miembro de l Instituto de Derechos Humanos de Estrasburgo Vasak (1984), pp. 15 y ss., para quien la categorización reflejaba una especie de orden temporal sucesivo, identificando tres generaciones de derechos que marchan de lo individual a lo solidario. La clasificación generacional también se encuentra en trabajos de otros autores clásicos como Bobbio (1991), pp. 10 y ss., para quien, aunque cronológicamente los derechos pueden clasificarse en generaciones, éstas serían cuatro, encontrando los derechos individuales, civiles y políticos; los económicos, sociales y culturales; los derechos asociados al medio ambiente; y por fin, una cuarta g eneración de derechos ligada al patrimonio genético de los individuos.

${ }^{6}$ No obstante, y tal como nos recuerda Gil (2015), pp. 22-23, no toda la doctrina está en sintonía con afirmar que exista una cuarta generación de derechos, entre otras razones, porque no se identifica con un cambio significativo en las estructuras del Estado. Sin embargo, existen varios autores que defienden la existencia de estas cuatro categorías, entre ellos véase Aguirre y Manasía (2015), pp. 2-16; Acata (2011), pp. 37-58; Morales (2016), pp. 39-66; Riofrío (2014), pp. 15-45; Del Río (2009), pp. 55-69; Valdés (2015), pp. 1197-1228; Vallespín (2002), pp. 31-32 y Morello (1994), pp. 88 y ss. Finalmente, hay quienes niegan totalmente la tesis generacional como Rabossi (1997), pp. 45 y ss., para quien la tesis carece de un valor teórico efectivo pues extiende el concepto de derecho humano hacia casos en los que no se sabe con precisión quiénes son los titulares, cuál es el interés jurídico que se protege y cuál es la índole de la protección jurídica que merecen.

${ }^{7}$ García (2007), p. 747.
} 
pollution -, término acuñado por algunos autores para referirse a la degradación de los clásicos derechos fundamentales ante los recientes usos de las nuevas tecnologías ${ }^{8}$.

En efecto, el desarrollo tecnológico acaecido desde la segunda mitad del siglo XX evidenció las limitaciones e insuficiencia del derecho a la intimidad —-derecho de primera generación-, como único mecanismo para dar respuesta a los peligros específicos que encierra el tratamiento automatizado de la información personal, por ello es que a partir de los años setenta, comenzó a gestarse la construcción dogmática y jurisprudencial de un nuevo derecho fundamental: el derecho a la protección de datos personales 9 .

Desde un punto de vista teórico, la reformulación de la clásica noción del derecho a la privacidad - right to privacy - ya no como un derecho de exclusión, como inicialmente había sido concebido, sino más bien como una facultad para controlar la información referente a uno mismo ${ }^{10}$, supuso un claro punto de quiebre en la conceptualización que hasta ese momento se había mantenido sobre el mismo ${ }^{11}$.

Por otro lado, en el contexto jurisprudencial, la conformación jurídica de este derecho —al que se calificó como derecho a la autodeterminación informativa - trae origen en una sentencia dictada por el Tribunal Constitucional Federal Alemán en el año 198312, al declarar la inconstitucionalidad de una ley que regulaba en ese entonces el proceso de censo demográfico ${ }^{13}$. Por contraste, la jurisprudencia chilena fue particularmente tardía en la configuración del derecho a la protección de datos personales ${ }^{14}$, ya que su primera aproximación se produjo en el año 1995, cuando el Tribunal Constitucional lo vinculó, precisamente, a la protección de la intimidad 15 .

\footnotetext{
${ }^{8}$ Pérez (2013), p. 168, y Sanz (2017), p. 141.

${ }^{9}$ Garriga (2016), p. 91.

${ }^{10}$ Gil (2015), p. 46.

${ }^{11}$ Debe mencionarse, por haber marcado un antes y un después, el trabajo de Alan F. Westin quien en 1967 publicó su obra Privacy and Freedom, texto que ofrece una nueva relectura del clásico The right to privacy formulado inicialmente por Warren y Brandeis. En aquella obra, Warren y Brandeis (1890), pp. 206, manifiestan la necesidad de contar con "un principio que pueda ser invocado para amparar la intimidad de la persona frente a la invasión de una prensa demasiado pujante, del fotógrafo, o del poseedor de cualquier otro aparato de grabación o reproducción de escenas o sonidos", (la traducción es nuestra). Este principio se materializa precisamente en el derecho a la privacidad, o como ellos llaman the right to privacy. Al respecto autores más contemporáneos como Nieves (2012), pp. 197-198, mantienen que la publicación de dicha obra fue el ensayo fundacional de la protección de la esfera privada en los Estados Unidos al dar forma a la clásica definición de privacidad, entendida como el derecho a ser dejado solo. Westin (1967), p. 7, por su parte, señala que "la privacidad es el reclamo de individuos, grupos o instituciones para determinar por sí mismos cuándo, cómo y a qué extender la información que se comunica a los demás" (La traducción es nuestra).

12 Tribunal Constitucional Federal Alemán, 209/85, de 15 de diciembre de 1983. Una traducción de la mentada sentencia está disponible en Schwabe (2009), pp. 95-102.

${ }^{13}$ Herrán (2003), p. 14, e Hidalgo (2017), p. 2.

${ }^{14}$ Quezada (2012), pp. 128 y ss.

15 Tribunal Constitucional, Rol Nº198-94, de 4 de enero de 1995. El control de constitucionalidad encomendado al tribunal recaía en un proyecto de ley que sancionaba el tráfico ilícito de estupefacientes, donde al Consejo de Defensa del Estado se le atribuía,
} 
Es cierto que el derecho a la intimidad constituye un antecedente importante, si no es que esencial, en lo que a la conformación del derecho objeto de nuestro estudio se refiere ${ }^{16}$, sin embargo, ello no significa que ambos deban confundirse, cuestión ésta que en su momento provocó innumerables debates ${ }^{17}$. Algunos autores, por ejemplo, afirmaron que el derecho a la protección de datos personales constituía una forma de manifestación de las particulares características que el derecho a la intimidad adquiere en la era informática, negando la autonomía que hoy es posible atribuirle ${ }^{18}$.

Desde nuestra perspectiva, y como ya se encargó de anunciar a inicios del presente siglo el Tribunal Constitucional español${ }^{19}$, conviven en nuestro ordenamiento jurídico dos derechos fundamentales íntimamente vinculados entre sí, a la par que claramente diferenciados: el derecho a la intimidad y el derecho a la protección de datos personales. Con el primero, se protege la confidencialidad de la información relativa a un individuo ${ }^{20}$, mientras que con el segundo se garantiza el buen uso de la información relativa a un sujeto, una vez que ésta ha sido revelada a un tercero, ya que el dato confesado no es por ello público y, en consecuencia, no puede circular libremente. Así, el poder jurídico de disponer y controlar en todo momento el uso y tráfico de esta información pertenece enteramente a su titular ${ }^{21}$. En otras palabras, el derecho fundamental a la protección de datos no constituye un derecho al secreto o a la reserva de los mismos, sino más bien una facultad de gobierno sobre su publicidad. De este modo, mientras

entre otras facultades, la de requerir la entrega de antecedentes o copias de documentos sobre cuentas corrientes bancarias, depósitos u otras operaciones sujetas a secreto o reserva de personas naturales o jurídicas que eran objeto de una investigación, pudiendo incautar todo tipo de documentación y antecedentes probatorios. El caso estaba vinculado directamente al tratamiento de datos personales, sin embargo, el tribunal hizo hincapié en la protección de la vida privada, res olviendo que "infringe también la disposición en análisis la garantía que contempla el número 5 del artículo 19 de la Constitución, que establece conjuntamente con el número 4, lo que la doctrina ha denominado el derecho a la intimidad de que gozan las personas y su familia".

${ }^{16}$ García (2007), p. 748.

${ }^{17}$ Herrán (2003), p. 12.

${ }^{18}$ De este lado, por ejemplo, Nogueira (2005), p. 449.

${ }^{19}$ El Tribunal Constitucional español, en sentencia 292/2000, de 30 de noviembre de 2000, se pronuncia del siguiente tenor liter al "el contenido del derecho fundamental a la protección de datos consiste en un poder de disposición y de control sobre los datos personales que faculta a la persona para decidir cuáles de esos datos proporcionar a un tercero, sea el Estado o un particular, o cuáles puede este tercero recabar, y que también permite al individuo saber quién posee esos datos personales y para qué, pudiendo oponerse a esa posesión o uso".

${ }_{20}$ En palabras de Lathrop (2013), p. 931, el derecho a la intimidad aspira a garantizar al individuo un ámbito de reserva excluyéndolo del conocimiento ajeno.

${ }^{21}$ Destaca en este punto lo señalado por el Tribunal Constitucional español, en sentencia 27/2020, de 24 de febrero de 2020, que viene a romper con la doctrina previa, referida a los condicionamientos necesarios para el legítimo uso por terceros de las imágenes publicadas en las redes sociales. En este sentido, la Corte Constitucional española considera que "la prestación para el consentimiento para la publicación de la propia imagen en internet conlleva el consentimiento para la difusión de esa imagen cuando tal difusión, por sus características, sea una consecuencia natural del carácter accesible de los datos o imágenes pub licados en internet, pues lo anterior no puede manifestarse como un consentimiento expreso para tal difusión, ni que el usuario lo haya aceptado implícitamente, debido a que el usuario tan solo ha consentido ser observado en el lugar que él ha elegido". 
que el derecho a la intimidad vendría siendo un poder de exclusión, el derecho a la protección de datos personales se consagra, en cambio, como uno de disposición ${ }^{22}$.

De acuerdo con lo esgrimido ut supra, parece ser esta última la posición adoptada finalmente por la Constitución chilena. Al respecto cabe recordar que la Organización para la Cooperación y el Desarrollo Económico (OCDE) apuntó, en el año 2015, que nuestro país se encontraba al debe en su normativa de protección de datos personales, señalando que entre sus Estados miembros, tan solo Chile y Turquía no habían perfeccionado aún su legislación sobre la materia ${ }^{23}$. En ese plano se enmarcó la reforma al artículo 19 número 4 del texto constitucional, el cual desde el pasado 16 de junio del año 2018 asegura a todas las personas ${ }^{24}$ "el respeto y protección a la vida privada y a la honra de la persona y su familia, y asimismo, la protección de sus datos personales", agregando que "el tratamiento y protección de estos datos se efectuará en la forma y condiciones que determine la ley"25. Como puede advertirse, el nuevo redactado de la norma fundamental chilena consagra ahora el derecho a la protección de datos personales de manera autónoma y diferenciada, tendencia ésta adoptada desde hace varios años por las cartas fundamentales de otros países de Europa y Latinoamérica, sumándose Chile a esta tendencia mayoritaria.

\section{2. ÁMBITO DE PROTECCIÓN}

El derecho fundamental a la protección de datos personales se concreta jurídicamente en la facultad de consentir la recogida, la obtención y el acceso a los datos personales de un individuo, así como su posterior almacenamiento, tratamiento y uso o usos posibles, por parte de un tercero, sea éste el Estado o un particular. Asimismo, también comprende tanto la facultad de conocer en todo momento quién dispone de esa información y a qué fines la está sometiendo, como el poder de oponerse a esa tenencia y utilización ${ }^{26}$.

\footnotetext{
22 Para García (2018), p. 4, el derecho a la protección de datos es un derecho subjetivo de naturaleza privada, que recae sobre un bien indispensable para reconocer la esencia misma de la persona, necesario para que pueda desarrollarse. En cuanto derecho de la personalidad, es un derecho innato, personalísimo (y por lo tanto individual, privado y absoluto o eficaz erga omnes) y extra patrimonial (en consecuencia, irrenunciable, indisponible, inexpropiable, inembargable, imprescriptible y extracommercium). En una línea similar, Martínez (2013), p. 174.

${ }^{23}$ En este sentido, es importante destacar que la Organización para la Cooperación y el Desarrollo Económico (OCDE), envió una carta de recomendación al Ministerio de Economía de Chile por el retraso que existía en el país en temas de protección de datos personales, acuerdo sellado en 2010 como parte del compromiso adquirido para ingresar a dicho organismo. Por lo tanto, fue un tema de especial importancia, al momento en que nuestro país comenzó a formar parte de dicha organización, la necesidad de adecuar la normativa vigente a los estándares internacionales de protección de la vida privada y flujo transfronterizo de datos. Cámara de Diputados de Chile (2016), p. 67.

${ }^{24}$ Esta reforma fue impulsada por la Ley № 21.096 que consagra el Derecho a la Protección de Datos.

${ }^{25}$ Nogueira (2019), p. 66, aboga por una mejora en los atributos y garantías de la regulación constitucional del que él denomina derecho a la autodeterminación informativa.

${ }^{26}$ Tribunal Constitucional español, 292/2000, de 30 de noviembre de 2000, fundamento jurídicos números 6 y 7.
} 
A tenor de lo preceptuado en la Ley N. ${ }^{\circ}$ 19.628, de 28 de agosto de 1999 (Ley de Protección a la Vida Privada, en adelante LPVP), que es la encargada de regular la materia en Chile, el derecho a la protección de datos permite a su titular disponer de la información que sobre sí mismo exista en los denominados "registros, ficheros o bancos de datos" cuya mantención precisamente permite ejecutar el "tratamiento" de dicha información ${ }^{27}$. En este sentido, la letra m) del artículo 2 de la LPVP, entiende por banco de datos "el conjunto organizado de información, automatizada o no, cualquiera sea la forma o modalidad de su creación u organización". Por tanto, para el legislador es indiferente si el tratamiento es o no automatizado, incluyendo ficheros computacionales y manuales.

Por su parte, la letra o) del mismo precepto entiende por tratamiento de datos "cualquier operación o procedimiento técnico que permita recolectar, almacenar, grabar, organizar, elaborar, seleccionar, extraer, confrontar, interconectar, disociar, comunicar, ceder, transferir, transmitir o cancelar datos de carácter personal, o utilizarlos en cualquier otra forma". En consecuencia, la norma comprende una serie de operaciones en donde cada una de ellas constituye por sí misma una forma de tratamiento de datos. De este modo, la sola operación de recogida ya implica la ejecución del tratamiento al que se viene aludiendo, por lo que la inclusión dentro de la definición de este conjunto de operaciones no implica que el tratamiento constituya un todo indivisible, pues el mismo puede estar compuesto de una, varias o todas las operaciones anteriormente descritas ${ }^{28}$.

Como derecho fundamental, la protección de datos personales debe incluir las facultades ARCO, es decir, aquellas relativas al acceso (conocer cuáles son los datos tratados), rectificación (requerir la modificación de aquellos consignados de manera errónea), cancelación (solicitar la destrucción de los datos cuando su tratamiento carezca de fundamento legal) y oposición (impedir que se lleve a cabo el tratamiento) ${ }^{29}$. A su vez, el artículo 16 de la LPVP dispone que es la acción de habeas data la destinada a hacer efectivas las garantías enumeradas, controlando de esta manera la información personal mantenida por los mentados ficheros.

Una aproximación al bien jurídico tutelado permite concluir que el fundamento último de este derecho no consiste exclusivamente en preservar oculta información, sino que, por el contrario, se centra más bien en garantizar el libre y pleno desarrollo de la personalidad. De hecho, fue el

\footnotetext{
${ }^{27}$ Muñoz (2015), p. 220.

${ }^{28}$ Heredero (1997), p. 86.

${ }^{29}$ Fundación Datos Protegidos (2017 a), p. 5.
} 
propio Tribunal Constitucional alemán, en la célebre sentencia aludida con anterioridad, el que identificó este vínculo, haciendo referencia a su vez al concepto de dignidad humana, cuyo deber de respeto es obligación de todo poder público ${ }^{30}$. Lo anterior conlleva, en definitiva, a impedir la instrumentalización del ser humano, que debe manifestarse en la sociedad con plena libertad, por ello, resulta consecuencia necesaria la configuración del derecho a la protección de datos personales como un derecho de la personalidad. Siendo esto así, el individuo demanda esta protección no sólo frente a los poderes públicos, sino también frente a la actuación de los particulares, por ejemplo, de las empresas privadas ${ }^{31}$.

Por otra parte, el concepto de dato personal constituye el núcleo esencial del derecho, ya que éste se erige como un modelo de protección que poseen los individuos frente al tratamiento que justamente de su información personal realizan terceros. En general, las leyes sobre protección de datos personales han venido definiendo este concepto en términos bastante amplios, entendiendo por tal, cualquier información concerniente a una persona, a lo menos determinable. En este sentido, la letra f) del artículo 2 de la LPVP entiende por dato personal “cualquier información concerniente a personas naturales, identificadas o identificables". Esta amplitud conceptual facilita su adaptación a la constante evolución tecnológica, no limitándose solamente a la información escrita, sino que también, a la información gráfica (como la imagen), numérica (como el número de cédula de identidad), alfabética (el nombre y los apellidos), u otra de cualquier índole 32 .

Además, la tendencia doctrinaria y legislativa ha clasificado todos estos datos con el objeto de establecer diversos niveles de protección. Por ejemplo, en atención a su origen, se distingue entre directos - datos entregados voluntariamente por su titular-, e indirectos - aquellos que han sido extraídos desde otros bancos de datos a partir de su comunicación mediante acceso, cesión u otro mecanismo análogo—. Esta clasificación, sin ir más lejos, es sumamente relevante con ocasión del consentimiento, toda vez que, tratándose de personas menores de edad, puede suceder que su declaración de voluntad no sea válida en atención a los requisitos exigidos por la normativa aplicable. Asimismo, se han distinguido datos personales sensibles y no sensibles. En ese sentido, la legislación nacional en su artículo 2 letra g), considera que datos sensibles son aquellos referidos a cuestiones de origen racial del titular, a sus opiniones políticas, convicciones

\footnotetext{
30 Muñoz (2015), p. 221.

31 Pulido (2011), p. 89.

32 En el ámbito de la legislación comparada, el artículo 4.1 del Reglamento 2016/679 del Parlamento Europeo, relativo a la protección de las personas físicas en lo que respecta al tratamiento de sus datos (en adelante RGPD), los ha definido en simi lares términos como "toda información sobre una persona física identificada o identificable".
} 
religiosas o filosóficas, conducta sexual y similares. Se trata, pues, de información personal a partir de la cual es posible se puedan efectuar discriminaciones arbitrarias respecto del individuo al cual se refieren. Por lo anterior, es común que en la mayoría de legislaciones, entre ellas la chilena, se establezcan requisitos más estrictos en cuanto al tratamiento de los datos sensibles, operando como punto de partida la prohibición de su tratamiento salvo que conste el consentimiento expreso de su titular. Con todo, pese a la aparente protección reforzada de la ley, la realidad indica que la especialidad de tales datos no es impedimento para que precisamente sean los más expuestos 33 .

Llegados a este punto, podríamos cuestionarnos acerca de si los datos de niños, niñas y adolescentes, como grupo poblacional en situación de particular vulnerabilidad, son por el hecho de ser tales, datos sensibles. Nuestra legislación no se pronuncia al respecto y tampoco los incluye en la enumeración del artículo 2 (letra g), sin embargo, por la misma naturaleza de la casuística recogida en dicho listado se debiese concluir que el mismo no alberga un catálogo cerrado o numerus clausus, circunstancia ésta que nos permitiría defender la inclusión de los datos relativos a personas menores de edad dentro de esa categorización ${ }^{34}$.

\section{La protección de datos personales de niños, niñas y adolescentes}

\subsection{LA CAPACIDAD NATURAL COMO ELEMENTO ESENCIAL PARA EL EJERCICIO DE LOS DERECHOS DE LA PERSONALIDAD}

La tendencia seguida por el ordenamiento jurídico chileno de otorgar relevancia a la denominada como capacidad natural —o madurez- como substrato esencial sobre el que fundamentar la capacidad de ejercicio de los niños, niñas y adolescentes, es especialmente marcada en el ámbito de los derechos de la personalidad —o dicho de otro modo, en el ámbito de los actos jurídicos extrapatrimoniales ${ }^{35}$ - y es precisamente en este contexto en el que surgieron las primeras voces partidarias de sostener que, si bien la dicotomía "capacidad de goce/capacidad de ejercicio" podía tener todavía cierta relevancia en el ámbito patrimonial, era, en cambio, insostenible en el ámbito de la personalidad -extrapatrimonial ${ }^{36}$ - Parece que

\footnotetext{
33 Troncoso (2010), p. 1693.

${ }^{34}$ El Proyecto de Ley de garantías y protección integral de los derechos de la niñez y la adolescencia —Boletín N N ${ }^{\circ}$ 10.315-18incorpora un precepto específico intitulado "vida privada y protección de datos personales", en el que se reconoce expresamente que "los niños, niñas y adolescentes tienen derecho a la protección de sus datos personales, así como a impedir el tratamiento o la cesión de estos, según lo establecido en la legislación vigente".

${ }^{35}$ Barcia (2013), pp. 3-ss., y Ravetllat (2016), pp. 213-224.

${ }^{36}$ Espejo (2016), p. 204, Varas (2010), p. 348, y Espejo y Lathrop (2015), p. 411.
} 
negar la capacidad de ejercicio en el espacio de los derechos de la personalidad cuando el sujeto, a pesar de su edad cronológica, reúne las condiciones intelectivas y volitivas suficientes para ejercitarlos por sí, se torna en una plausible vulneración a la dignidad y al libre desarrollo de la personalidad del individuo 37 , reconocidos en el artículo 1 de nuestra Constitución como valores superiores del sistema normativo (Las personas nacen libres e iguales en dignidad y derechos).

Ciertamente, se ha discutido si es aplicable en el campo de los derechos de la personalidad la distinción entre capacidad de goce y capacidad de ejercicio, ya que el goce o ejercicio de estos derechos es personal. De ahí que difícilmente pueda hablarse en este entorno de auténtica representación legal, matizándose mucho esta representación o configurándose más bien como una asistencia o una actuación de los progenitores o tutores/curadores en cumplimiento de su deber de velar por el niño, niña o adolescente, especialmente justificada cuando se trate de evitarle un perjuicio 38 .

Sentado lo anterior y en consonancia con el principio del favor filii, la puesta en acción de los derechos de la personalidad por sus legítimos titulares, sólo cabe limitarla cuando su voluntad de activarlos sea contraria a intereses preponderantes en atención al pleno desarrollo de su personalidad, de la misma forma que se puede limitar la voluntas de sus representantes cuando su intervención sea contraria a los intereses del niño, niña o adolescente ${ }^{39}$.

Pues bien, es precisamente en ese contexto, en el que emerge con fuerza la idea de adoptar el criterio de la madurez suficiente, el autogobierno o la capacidad natural, como pauta a seguir para delimitar el ejercicio autónomo de los derechos de la personalidad, evitándose con ello que la persona que no ha alcanzado todavía la mayoría de edad sea simplemente titular del derecho, pero no pueda, en cambio, ejercitarlo. De este modo, la regla general se torna en que la niña, niño o adolescente que presente suficiente madurez pueda disponer libremente de su derecho ${ }^{40}$.

Significado lo anterior, se debe apuntar que ante ese nuevo escenario la cuestión se circunscribe en concretar qué se entiende por ostentar madurez suficiente, pues nos encontramos ante un concepto jurídico indeterminado en torno al cual no existe una definición

\footnotetext{
${ }^{37}$ Para Gil (2015), p. 28, la personalidad del individuo se funda en los valores superiores de la dignidad y la libertad, configurándose la misma como un valor unitario situado en el epicentro de todo nuestro ordenamiento jurídico.

${ }^{38}$ Andreu (2013), p. 70, Santos (2011), p. 64, y Godoy (2018), p. 12.

${ }^{39}$ Estamos pensando, ad exemplum, en la posible afectación de un niño, niña o adolescente por facilitar cierta información acerca de su vida privada, e incluso la denegación del acceso a su expediente académico y/o médico a sus representantes legales sin mediar causa justificada alguna, situaciones todas ellas que, por definición, podrían ser contrarias a su propio interés superior, que es, in fine, el objetivo último al que se pretende atender.

${ }^{40}$ Lorente (2015), p. 92, Ravetllat (2017), pp. 30-44, Bartolomé (2015), pp. 80-104, y Lama (2006), pp. 45-56.
} 
legal unificada. Cada niño y niña es diferente, y por ende es muy difícil establecer cuándo ostenta o no la capacidad de ejercicio necesaria, debido a su desarrollo intelectual, para poder ser dueño de su propia persona ${ }^{41}$.

\subsection{DÉFICIT Y DISPARIDAD NORMATIVA}

Si es un hecho el que las relaciones sociales se canalizan cada vez de manera más intensa a través de los cauces electrónicos, aspecto en el que las personas menores de edad destacan sobre otros sectores de la población, debemos considerar si efectivamente contamos en Chile con una regulación que garantice la protección efectiva de los/as ciudadanos/as en este contexto material, o si por el contrario, resulta ser insuficiente para implementar los mecanismos que a tales efectos serían precisos.

A propósito de ello, es preciso señalar que el derecho a la protección de datos personales ha tenido un desarrollo asimétrico en los diferentes sistemas de derechos humanos. De hecho, la realidad actual se caracteriza por presentar diferencias sustantivas entre países, bien por la inexistencia de normatividad en algunos casos, bien por las aproximaciones divergentes a la cuestión en otros, que inciden, sin lugar a duda, en la falta de protección efectiva de sus titulares, muy en particular si se trata de niños, niñas y adolescentes.

Además, no debe obviarse que por regla general, la normativa que regula el tratamiento de datos se caracteriza por una sobreutilización de criterios generales, debiendo acudirse, en todo caso, para tener una visión más completa y detallada del asunto, a la normativa sectorial correspondiente. Así sucede, por ejemplo, en el ámbito educativo (datos personales manejados por establecimientos educacionales) ${ }^{42}$, en el sanitario (datos personales médicos) ${ }^{43}$ o en el judicial (datos de adolescentes infractores de ley) ${ }^{44}$, lo que tampoco garantiza que, en los mentados ámbitos, existan disposiciones que reconozcan de forma expresa a las personas menores de edad como destinatarias de las mismas, incluyéndolas sólo en su régimen general.

\footnotetext{
${ }^{41}$ Moreno (2017), p. 137.

${ }^{42}$ Como manifiesta Donoso (2009), pp. 57-58, desde que un niño/a ingresa al sistema educacional, las instituciones en las cuales cursa sus estudios acopian una cantidad no desdeñable de sus datos, los que son usados para diversas finalidades. No olvidar que, conforme al concepto legal, no es necesario que el tratamiento sea automatizado, bastando un sistema manual de organización de información, como libros de clases, pruebas rendidas por el o la estudiante, u otros instrumentos.

${ }^{43}$ En este caso el Comité de los Derechos del Niño ha señalado en su Observación General número 4 que "los trabajadores de la salud tienen la obligación de asegurar la confidencialidad de la información médica relativa a los adolescentes, teniendo en cuenta los principios básicos de la Convención". Comité de los Derechos del Niño (2003), p. 4.

${ }^{44}$ El Comité de los Derechos del Niño también se ha pronunciado sobre el tratamiento de los datos de personas menores de edad y su inclusión en registros de antecedentes penales, recomendando en su Observación General número 10 que: "los Estados Partes adopten normas que permitan la supresión automática en los registros de antecedentes penales del nombre de los niños cuando éstos cumplan 18 años". Comité de los Derechos del Niño (2007), p. 20.
} 
De forma preliminar al análisis de las previsiones contenidas en el ordenamiento jurídico chileno, nos detendremos, si bien brevemente, en la descripción de los principales cuerpos legales vigentes que tratan sobre la materia en el ámbito internacional propiamente dicho, además del europeo - por ser uno de los referentes más avanzados-, y, por último, en el contexto latinoamericano.

Partiendo por el panorama internacional, una revisión generalizada del mismo nos lleva a afirmar que no hay texto internacional alguno que consagre expresamente el derecho a la protección de datos personales en favor de niños, niñas o adolescentes. Ahora bien, la Convención sobre los Derechos del Niño sí reconoce en su artículo 16 una garantía vinculada, como es el derecho a la vida privada, el que a su vez se inspira en el artículo 12 de la Declaración Universal de los Derechos del Hombre y en el artículo 17 del Pacto Internacional de Derechos Civiles y Políticos, aplicables ambos, por supuesto, a la infancia y la adolescencia ${ }^{45}$. En atención a dicha omisión, corresponde especialmente a los órganos de interpretación de los tratados de derechos humanos de Naciones Unidas, en nuestro caso al Comité de los Derechos del Niño, el pronunciarse sobre las consecuencias que el tratamiento incorrecto o ilícito de datos pueda provocar en los niños, niñas y adolescentes, ello mediante la interpretación de las disposiciones cuyo contenido se acerca o vincula con el derecho objeto de nuestro análisis.

Lo anterior no debiese resultarnos extraño, pues como parte de la doctrina nacional ha indicado, constituye una característica propia de los instrumentos internacionales de Derechos Humanos el que su redacción positiva no recoja expresamente la evolución doctrinal del contenido de este tipo de derechos, y por ello, aunque la literalidad de sus preceptos no evidencien el dinamismo con que la voz experta los va desarrollando, de igual manera sus disposiciones deben ser leídas de forma dinámica, acorde con las nuevas circunstancias que puedan irse presentando 46 .

Más allá de los citados instrumentos internacionales, lo que sí encontramos son un conjunto de directrices encargadas de establecer los principios generales de todo tratamiento de datos, en los que debemos entender incluidos los casos vinculados con las personas menores de edad. En este sentido, ad exemplum, la Resolución 45/95 de la Asamblea General de las Naciones Unidas del año 1990, que trata los "principios rectores sobre la reglamentación de los ficheros

\footnotetext{
${ }^{45}$ Rizik (2019), p. 451. Por su parte, Lovera (2009 b), p. 15, apunta que el cambio que introduce la Convención no solo confirma la titularidad de los niños y adolescentes sobre sus derechos constitucionales, sino que, además, y más importante, que ellos y ellas tienen un rol protagónico, del que antes estaban privados, en la decisión de cómo ejercer y proteger sus derechos.

${ }^{46}$ Lathrop (2013), p. 933.
} 
computadorizados de datos personales", la cual menciona garantías mínimas como la licitud, exactitud o finalidad para el tratamiento de datos. También a este respecto resulta relevante la labor llevada a cabo por la OCDE, la cual publicó en 1980 las "directrices sobre protección de privacidad y el flujo transfronterizo", que se convirtieron en el germen de la normativa latinoamericana, aunque en ella no existe referencia explícita alguna a los datos personales de niños, niñas y adolescentes ${ }^{47}$.

De igual forma, en lo relativo al ámbito regional, y concretamente en la comunidad latinoamericana, tal como ocurre a nivel internacional, no existe norma expresa que regule el tratamiento de los datos personales de niños, niñas y adolescentes. Tan solo de manera indirecta podríamos acudir al artículo 11.2 de la Convención Interamericana de Derechos Humanos derecho a la vida privada-. Ahora bien, no obstante lo apuntado, puede decirse que estos Estados sí han avanzado, en líneas generales, en el desarrollo y regulación de la materia por medio de algunas iniciativas no vinculantes, dentro de las cuales destaca el Memorándum de Montevideo, sobre la protección de datos personales en las redes sociales e internet, en particular de niños, niñas y adolescentes. Este instrumento del año 2009, dirigido a los países de América Latina y el Caribe, recoge algunas recomendaciones sobre el tratamiento de datos de personas menores de edad, siendo destacable que utiliza como referente principal la Convención sobre los Derechos del Niño, señalando la necesidad de que todas las medidas adoptadas en la materia prioricen el principio del interés superior. Además, recomienda en su punto número 8, legislar el derecho que ostentan niños, niñas y jóvenes, directamente o por medio de sus representantes legales, a solicitar el acceso a la información que sobre sí mismos se encuentran en bases de datos, tanto públicas como privadas, a la rectificación o cancelación de la información, así como la oposición a su uso para cualquier fin ${ }^{48}$.

En contraste a lo anteriormente descrito, es en el marco de la Unión Europea donde este derecho ha encontrado mayor nivel de desarrollo normativo ${ }^{49}$, en especial desde su reconocimiento como derecho fundamental en el artículo 8 de la Carta de los Derechos Fundamentales ${ }^{50}$ y en el Convenio número 108 del Consejo de Europa, para la protección de las personas respecto al tratamiento automatizado de sus datos. Asimismo, además de las referidas

\footnotetext{
${ }^{47}$ Red Iberoamericana de Protección de Datos (2016), p. 159.

48 Para acceder al documento completo del Memorándum de Montevideo vid. https://bit.ly/3x5ViF4 (acceso el 27 de marzo de 2020).

${ }^{49}$ Maqueo et al. (2017), p. 81.

${ }^{50}$ La Carta de los Derechos Fundamentales de la Unión Europea, en su artículo 8.1, señala lo siguiente: "Toda persona tiene derecho a la protección de los datos de carácter personal que la conciernan".
} 
normas vinculantes que lo reconocen y regulan de forma explícita, también encontramos otras disposiciones que contienen referencias expresas al tratamiento de datos de niños, niñas y adolescentes. Este es el caso del Reglamento (UE) 2016/679, del Parlamento y el Consejo, de 27 de abril de 2016, relativo a la protección de las personas físicas en lo que respecta al tratamiento de sus datos personales y a la libre circulación de esos datos —en adelante RGPD—, cuyo contenido (obligatorio para los Estados de la Unión Europea desde mayo de 2018) vino a reemplazar la antigua Directiva 95/46/CE sobre Protección de Datos ${ }^{51}$.

Por último, y en lo que se refiere a la situación particular de nuestro país, Chile cuenta con una anacrónica Ley $N^{\circ} .19 .628$ sobre Protección de la Vida Privada, la cual data del año 1999, y que ha sido permanentemente cuestionada por una serie de falencias normativas. Entre ellas se han mencionado: la falta de una institucionalidad necesaria en el sentido de no entregar a ningún organismo público facultades de fiscalización y sanción 52 ; el hecho de garantizar la protección de datos sólo a posteriori en razón de una acción de habeas data cuya competencia recae en un juez no especializado ${ }^{53}$; la falta de un registro de banco de datos privados ${ }^{54}$ que permita conocer cuáles serían las empresas particulares que ejecutan el tratamiento; así como, y en directa relación con el tema estudiado, la falta de pronunciamiento respecto al tratamiento de datos personales de niños, niñas y adolescentes ${ }^{55}$.

En definitiva, el reconocimiento (o la falta de este) del derecho a la protección de datos personales en los instrumentos internacionales citados, así como su necesaria interpretación jurisprudencial, pone de manifiesto las asimetrías que se presentan en cada sector. La falta de estándares comunes entre las distintas regiones además de entorpecer el intercambio entre países (por las restricciones a la libre circulación transfronteriza de los datos personales) afecta el bienestar de los individuos, tanto por la seguridad de los datos como por la dificultad para que las administraciones locales cumplan los cometidos que les incumben, donde en particular

\footnotetext{
${ }^{51}$ Con independencia de todos estos instrumentos legales, en el ámbito europeo existe también un órgano consultivo independiente llamado "Grupo de Trabajo del Artículo 29" (creado por el artículo 29 de la Directiva 95/46/CE), que se ha pronunciado en diversos dictámenes sobre el tratamiento de datos personales de los sujetos menores de edad.

${ }^{52}$ La Ley № 20.285, sobre acceso a la "información pública", encomienda al Consejo para la Transparencia velar por el adecuado cumplimiento de la LPVP, por parte de estos servicios, sin consagrar un organismo que fiscalice el resto de casos.

${ }^{53} \mathrm{~A}$ modo de ejemplo, la Ley $\mathrm{N}^{\circ} 19.628$, en su artículo 16 dispone que, si el responsable del banco de datos no se pronuncia sobre la solicitud del requirente, el titular tiene derecho a recurrir al juez de letras en lo civil. Una crítica en este sentido, la vierte Álvarez (2016), p. 53, quien sostiene que si bien la Ley $\mathrm{N}^{\circ} 19.628$ reconoce una serie de derechos a las personas naturales titulares de los datos, estos deben ser ejercidos ante tribunales civiles, en procedimientos de larga y costosa tramitación, lo que constitu ye una barrera para el ciudadano común.

${ }^{54}$ Herrera (2016), p. 93.

55 Precisamente por ello, Jervis (2002), p. 26, propone la posibilidad de ejercicio de la acción de habeas data por medio de representante legal. Esta autora justifica tal conclusión debido a la finalidad de la ley, que es justamente brindar protección a los titulares de datos personales, dentro de los cuales pueden encontrarse niños, niñas y adolescentes.
} 
niños, niñas y adolescentes, por sus especiales características, se presentan como un colectivo social en clara desventaja 56.

\subsection{TITULARIDAD DEL DERECHO A LA PROTECCIÓN DE DATOS PERSONALES}

Partiendo de la idea de que el mero hecho de ser persona confiere la capacidad de goce artículo 74 del Código Civil一, resulta obvio el manifestar que esa aptitud también comprende, a los efectos que ahora nos atañen, la plena titularidad del derecho de protección de datos personales, máxime cuando se trata de un derecho fundamental contenido en el numeral 4 del artículo 19 de la Constitución Política de la República de Chile.

Efectivamente, el texto constitucional asegura a todas las personas, con independencia de su rango etario, la protección de sus datos personales, añadiendo que el tratamiento y protección de los mismos se efectuará en la forma y condiciones que determine la ley ${ }^{57}$. En este mismo sentido, si bien haciendo referencia a otro de los derechos de la personalidad, se pronunció el Tribunal Constitucional, Rol $N^{\circ}$. 740, de 18 de abril de 2008, al reconocer que los y las adolescentes, al igual que cualquier otra persona, son titulares de los derechos constitucionales y además, que a ellos y ellas corresponde proteger en su ejercicio legítimo, esto es, ya no como apéndices de un ejercicio que se define de manera exógena, sino que a partir de ellos mismos.

A mayor abundamiento, la Ley $\mathrm{N}^{\circ}$. 19.628, sobre protección de la vida privada, en su artículo $1^{\circ}$ al establecer que "toda persona puede efectuar el tratamiento de datos personales, siempre que lo haga de manera concordante con esta ley y para finalidades permitidas por el ordenamiento jurídico", así como al definir, en su artículo $2^{\circ}$ letra ñ, como titular de los datos, "la persona natural a la que se refieren los datos de carácter personal", no excluye, en modo alguno, a los sujetos por razón de su edad, ni tampoco nada estipulan con respecto a la capacidad exigida para poder hacer efectivo dicho derecho, por ende, no debiera presumirse que se está excluyendo a los niños, niñas y adolescentes, pues tal interpretación, in abstracto, sería contraria al espíritu dimanante de los preceptos de la Convención sobre los Derechos del Niño, tratado internacional ratificado y, en consecuencia, aplicable en nuestro ordenamiento jurídico.

Trasladando ahora nuestra mirada al ámbito internacional, la Convención sobre los Derechos del Niño se reafirma en esa línea argumental, al reconocer expresamente a los niños, niñas y

\footnotetext{
${ }_{56}$ Para Millaleo (2015), p. 40, precisamente esas dificultades de los Estados para regular el ecosistema digital significan que en este sector prolifera el modelo de autorregulación por parte de la industria relevante de este sector.

57 Corroboran esta línea de pensamiento Lovera (2017), p. 165, y Lathrop (2017), p. 231.
} 
adolescentes la titularidad del derecho a la protección de la vida privada, "no pudiendo ser objeto de injerencias arbitrarias o ilegales en su vida privada, su familia, su domicilio o su correspondencia, ni de ataques ilegales a su honra y a su reputación”, —artículo 1658_.

Asimismo, el artículo 11 de la Convención Americana sobre Derechos Humanos, estipula que "toda persona tiene derecho al respeto de su honra y al reconocimiento de su dignidad", añadiendo, acto seguido, que "nadie puede ser objeto de injerencias arbitrarias o abusivas en su vida privada, en la de su familia, en la de su domicilio o en su correspondencia, ni de ataques ilegales a su honra y reputación". Este precepto, por ende, tampoco excluye a niños, niñas y adolescentes de la titularidad del derecho objeto de nuestro análisis ${ }^{59}$. Además, tal lectura es corroborada tanto por la Opinión Consultiva 21/1460 como por la más reciente Opinión Consultiva 24/1761, ambas de la Corte Interamericana de Derechos Humanos (Corte IDH, en adelante).

En la primera, se establece que las niñas y niños ejercen por sí mismos sus derechos de manera progresiva, a medida que desarrollan un mayor nivel de autonomía personal 62 . Precisamente, este es uno de los motivos por los que la Convención Americana sobre Derechos Humanos dispone que las medidas de protección a favor de las niñas y de los niños sean especiales o más específicas que las que se decretan para el resto de las personas, es decir, los adultos $^{63}$. Así, la Corte señala que las niñas y niños gozan de los mismos derechos que los adultos y, además, posen derechos adicionales y, por tanto, el artículo 19 debe entenderse como un derecho adicional, complementario, que el tratado establece para sujetos que por su desarrollo físico y emocional necesitan de una protección especial ${ }^{64}$.

En la segunda, la Corte IDH nos recuerda nuevamente que conforme ha señalado en reiterados casos, las niñas y niños son titulares de los mismos derechos que los adultos, —son,

\footnotetext{
${ }^{58}$ Para un estudio en profundidad de los pasos seguidos en la redacción definitiva del artículo 16 de la Convención sobre los Derechos del Niño ver Detrick et al. (1992), pp. 256-270.

${ }^{59}$ Nogueira (2017), p. 420.

${ }^{60}$ Corte IDH: Opinión Consultiva OC-21/14, de 19 de agosto de 2014. Serie A № 19.

${ }^{61}$ Corte IDH: Opinión Consultiva OC-24/17, de 24 de noviembre de 2017. Serie A № 24.

${ }^{62} \mathrm{La}$ Corte IDH en diversas sentencias también ha adoptado idéntico criterio: Corte IDH: Caso Atala Riffo y niñas vs. Chile. Fondo, Reparaciones y Costas. Sentencia de 24 de febrero de 2012. Serie C №. 239, parr. 197; Corte IDH: Caso Furlan y familiares vs. Argentina. Fondo, Reparaciones y Costas. Sentencia de 31 de agosto de 2012. Serie C No. 148, parr. 230; y Corte IDH: Caso Mendoza y otros vs. Argentina. Fondo, Reparaciones y Costas. Sentencia de 14 de mayo de 2013. Serie C No. 260, parr. 143.

${ }^{63}$ Corte IDH: Caso Gelman vs. Uruguay. Fondo, Reparaciones y Costas. Sentencia del 24 de febrero de 2011. Serie C №. 239, parr. 121, y Corte IDH: Condición jurídica y derechos humanos del niño. Obligaciones estatales con el propósito de determinar si las medidas especiales establecidas en el artículo 19 de la CIDH constituyen límites al arbitrio o la discrecionalidad de los Estados en relación a niños (interpretación y alcance de los artículos 8 y 25 de la Convención Americana sobre Derechos Humanos). Opinión Consultiva OC-17 de 28 de agosto de 2002. Serie A №. 17, parr. 24.

${ }^{64}$ Corte IDH: Opinión Consultiva OC-21/14 de 19 de agosto de 2014. Serie A №. 19, parr. 66.
} 
en definitiva, sujetos titulares de derechos-, y que, además, cuentan con las medidas especiales de protección contempladas en el artículo 19 de la Convención, las cuales deben ser definidas según las circunstancias particulares de cada caso concreto ${ }^{65}$.

Por último, para cerrar este apartado, y en desarrollo de las previsiones contenidas tanto en el texto de la Convención sobre los Derechos del Niño como en la Convención Americana sobre Derechos Humanos, el Proyecto de Ley de Garantías y Protección Integral de los Derechos de la Niñez y la Adolescencia (Boletín Nº.10.315-18), en estado avanzado de tramitación en el Senado chileno, además de reconocer en su artículo 6 que "todo niño, niña y adolescente es titular y goza plenamente de los derechos reconocidos en la Constitución Política de la República, en la Convención sobre los Derechos del Niño, en los demás tratados internacionales ratificados por Chile que se encuentren vigentes, y en las leyes", viene también a romper con el silencio que tradicionalmente ha caracterizado el ordenamiento jurídico chileno en estas cuestiones. Así, el artículo 21 de este Proyecto - artículo 31 tras el texto adoptado por la Comisión especial de infancia del Senado - atribuye a las niñas, niños y adolescentes "el derecho a la vida privada y a la protección de datos personales", en un sentido similar y coherente con el introducido en el texto constitucional —numeral $4^{\circ}$ del artículo 19- por su reforma del año 2018.

\section{Capacidad de niños, niñas y adolescentes para la libre disposición de su información personal}

\subsection{CONSENTIMIENTO DIGITAL PRESTADO POR NIÑOS, NIÑAS Y ADOLESCENTES: MODELO COMPARADO Y PROPUESTA DE APLICACIÓN EN CHILE}

La prestación del consentimiento para el tratamiento de datos se configura como una declaración de voluntad (libre, específica, informada e inequívoca) del titular de tales datos que precisa inexorablemente de la aptitud del sujeto de entender y de querer ese tratamiento, y constituye una manifestación de su capacidad de ejercicio. Por ende, únicamente las personas que ostenten tal facultad estarán legitimadas para prestar tal declaración de voluntad ${ }^{66}$.

Acudimos en este punto a las previsiones contenidas tanto en el RGPD europeo como al desarrollo que del mismo se ha efectuado en el Derecho español, por tratarse ambos textos

\footnotetext{
${ }^{65}$ Corte IDH: Opinión Consultiva OC-24/17 de 24 de noviembre de 2017. Serie A №. 24, parr. 149.

${ }^{66}$ Interesante es lo que apunta Gil (2015), p. 147, al destacar que al ser personas menores de edad las que se incorporan mayoritariamente a las redes sociales, ello debiera traducirse en un requerimiento de mayor claridad y fácil accesibilidad a la información, mediante la existencia de pantallas amigables, con un lenguaje sencillo.
} 
normativos de claros referentes que pudieran ser tomados en consideración en Chile como un modelo a partir del cual abordar el vacío legal existente en esta materia. Pues bien, el RGPD se pronuncia sobre el tema en su artículo 8, intitulado "condiciones aplicables al consentimiento del niño en relación con los servicios de la sociedad de la información", sentando un ámbito de protección específico delimitado a este tipo de servicios, dentro de los cuales, evidentemente se encuentran las redes sociales. Esto podría hacernos pensar que el tratamiento de datos fuera de dicho ámbito — sociedad de la información—, queda desprotegido por el Reglamento europeo, sin embargo, tal interpretación no parece acertada al ir en contra de la protección integral que precisamente es la buscada, lo que significa que tales reglas pueden, o más bien deben, ser extrapolables a otros supuestos, numerosos por cierto, que pueden darse fuera de la red. Posteriormente, siguiendo esos parámetros, el legislador español adaptó su normativa interna a las prevenciones del Reglamento europeo con la Ley Orgánica 3/2018, de 5 de diciembre, de Protección de datos personales y garantía de los derechos digitales —en adelante LOPD—, que en su artículo 7, que lleva por rúbrica "consentimiento de los menores de edad", aborda la cuestión desde un marco de protección omnicomprensivo que incluye cualquier tipo de tratamiento de datos personales.

Desde la perspectiva que ahora nos atañe, examinando concretamente las referencias al criterio de edad adoptado a los efectos de la licitud del consentimiento manifestado por las personas menores de edad, la LOPD (2018) española distingue -artículo 7- entre sujetos mayores y menores de 14 años, donde los primeros pueden otorgar su consentimiento de manera autónoma, salvo que la ley exija lo contrario, mientras que los segundos derechamente requieren del consentimiento de sus padres o tutores ${ }^{67}$. Por el contrario, la normativa comunitaria -artículo 8- fija el punto en los 16 años, indicando que bajo dicha edad el tratamiento únicamente se considerará lícito si el consentimiento lo dio o autorizó el titular de la patria potestad o tutela. Pese a ello, la disposición europea agrega que los Estados miembros pueden establecer por ley una edad inferior a tales fines, siempre que esta no esté por debajo de los 13 años. Esto significa que el RGPD estatuye un abanico o intervalo de opciones entre los 13

\footnotetext{
${ }^{67}$ Esta franja etaria de los 14 años acogida por el artículo 7 de la LOPD (2018) trae origen en la teoría elaborada, desde inicios del año 2000, por la Agencia Española de Protección de Datos, en respuesta a las carencias normativas existentes en el ordenamien to jurídico español de la época. Posteriormente, toda esa labor in tegradora del sistema fue recogida por el Real Decreto 1720/2007, de 21 de diciembre, por el que se aprobó el Reglamento de desarrollo de la Ley Orgánica 15/1999, de 13 de diciembre, cuyo art ículo 13 se dedicó íntegramente a la forma cómo debe obtenerse el consentimiento para el tratamiento automatizado de datos pertenecientes a niños, niñas y adolescentes. Para el análisis detallado de esta evolución acaecida en la normativa española vid. Orozco (2010), pp. 386-387; Zabía De La Mata (2008), p. 188; Guerrero (2006), p. 277; y Chaveli y Picazo (2003), p. 2.
} 
y 16 años de edad, lo cual permite unificar la disparidad de criterios normativos existente entre los diversos Estados miembros de la Unión Europea.

Llegados a este punto, y tomando en consideración lo manifestado en epígrafes anteriores, donde se incidió en la particular naturaleza — como derecho de la personalidad-, del derecho a la protección de datos personales, podemos plantearnos, a la vista de los modelos español y europeo, si la capacidad natural —madurez — ha sido realmente tomada en consideración para delimitar quién ostenta legitimación activa para ejercer tal derecho. En otras palabras, si la edad fijada -14 años en España y 16 en el Reglamento europeo- para la válida prestación del consentimiento digital se erige en un elemento cronológico objetivo completamente estático, o, por el contrario, se configura como una mera presunción iuris tantum, por ende dinámica, que admite prueba en contrario ${ }^{68}$.

En nuestra opinión, la edad debiera actuar en estos casos más como presunción iuris tantum que iuris et de iure, y admitir prueba en contrario. Lo anterior debido a que el concepto ecuánime de la edad por sí solo podría conducirnos a situaciones que no se corresponden con la realidad. Evidentemente, la edad constituye un criterio útil y objetivo al cual acudir, sin embargo, al ser considerado el único factor válido podría insertar un alto grado de arbitrariedad en la resolución de los conflictos relacionados con el consentimiento de las personas menores de edad, por ello nos parece una buena opción legislativa optar por un sistema mixto, que combine el criterio objetivo de edad acompañándolo de la posibilidad de demostrar lo contrario echando mano al concepto de madurez sólo en caso de conflicto.

Ahora bien, en contraposición al adelantado panorama europeo, la eficacia del consentimiento de las personas menores de edad sobre sus datos personales sigue sin estar definida expresamente en Chile. Para superar esta omisión, primeramente no debemos perder de vista que nos encontramos ante un derecho de la personalidad, y si bien nuestra legislación nacional tampoco se pronuncia expresamente acerca de la procedencia o no de la representación en materias relacionadas con este tipo de derechos, tal circunstancia no puede traer como consecuencia la aplicación automática a este tipo de cuestiones de las categorías contenidas en

\footnotetext{
${ }^{68}$ Pareciera ser que la segunda de las opciones planteadas fue por la que se decantó la Agencia Española de Protección de Datos. Este organismo de Derecho público se pronunció por primera vez sobre la cuestión en su Memoria de Actividades del año 2000 defendiendo la idea de que las personas con catorce años disponen de las condiciones de madurez necesarias para consentir por sí. Esta interpretación fue posteriormente ratificada por el Informe Jurídico 466/2004, en el que la Agencia resolvió una consulta relativa a la obligatoriedad o no de la comunicación a los progenitores, por parte de los centros educativos, de las califica ciones escolares obtenidas por sus hijos/as menores de edad.
} 
el artículo 26 del Código Civil chileno, pensadas e ideadas, más bien, para un contexto patrimonial contractual 69 .

En efecto, en el Derecho actual puede considerarse asentada la idea, que ya avanzábamos en epígrafes anteriores, según la cual, en el ámbito de los derechos de la personalidad no rigen las reglas generales de capacidad aplicables al campo patrimonial, dado que el núcleo básico de estos es la libertad y la dignidad del individuo, y su ejercicio contribuye al libre desarrollo de la personalidad, por lo que en general, en este contexto se debiese permitir a todo sujeto tomar sus propias decisiones ${ }^{70}$. Para el eficaz ejercicio de los derechos de la personalidad basta pues que el titular ostente capacidad natural, es decir, que el sujeto disponga de suficiente juicio en relación con el acto jurídico determinado que se pretende desarrollar ${ }^{71}$. Esto, llevado al ámbito de los derechos de la infancia y la adolescencia, nos remite a las nociones de "evolución de facultades" y "autonomía progresiva”, sostenidos en los artículos 5 y 12 de la Convención sobre los Derechos del Niño.

Ahora bien, en cuanto a la determinación de la capacidad en materia extrapatrimonial, se ha entendido que la apreciación casuística es fundamental, lo que involucra la evaluación de una serie de factores o criterios aplicables a la situación particular de que se trate. Para Santos Morón ${ }^{72}$, en esta determinación uno de aquellos factores es precisamente la edad de la persona, por tanto, no habría impedimento para que en algunos casos la ley establezca un rango etario a partir del cual se presuma la capacidad del niño, niña o adolescente para ejercer determinados actos.

En un sentido similar se pronuncia el profesor Barcia Lehmann, quien desarrollando esta idea señala que en la determinación de esta capacidad extrapatrimonial se debe atender a ciertos criterios plenamente aplicables en Chile, los cuales serían la edad (como regla general), la madurez (como criterio basal), la entidad del acto (como criterio fundamental) y el principio de protección de la infancia y la adolescencia (como límite a la capacidad). En cuanto al factor edad para este autor resulta fundamental la diferenciación entre las categorías de niño/a y adolescente definidas a partir del artículo 16 inciso 3 de la Ley $\mathrm{N}^{\circ}$. 19.968, el cual considera niño o niña a todo ser humano que no ha cumplido los catorce años, y adolescente a quien se encuentra entre los catorce y los dieciocho años de edad. La importancia de esta distinción

\footnotetext{
${ }^{69}$ Barcia (2013), p. 5.

${ }^{70}$ Santos (2011), p. 63.

${ }^{71}$ Ravetllat (2017), p. 7.

${ }^{72}$ Santos (2011), p. 64.
} 
recaería en que, por regla general, se presume que los adolescentes son plenamente capaces respecto del ejercicio de sus derechos extrapatrimoniales, mientras que los niños y las niñas no lo son ${ }^{73}$.

El desarrollo de esta idea nos parece sumamente útil para comprender lo que sucede en el derecho a la protección de datos personales, toda vez que tal diferenciación resulta coincidente con la forma en que el Derecho Comparado ha abordado el consentimiento del niño/a y adolescente en el ejercicio de este derecho de la personalidad. En efecto, como ya se ha descrito en el presente trabajo, esta es la situación imperante en España, donde los mayores de 14 años pueden otorgar autónomamente su consentimiento - salvo excepciones-, mientras que por debajo de esta edad se requiere la autorización del representante legal. De manera análoga, en otras latitudes también se ha aplicado una lógica parecida, como es el caso peruano, donde el Reglamento de la Ley N². 29.733 de Protección de Datos Personales dedica un capítulo especial a los niños, niñas y adolescentes, estableciendo en su artículo 27 que "para el tratamiento de los datos personales de un menor de edad, se requerirá el consentimiento de los titulares de la patria potestad o tutores, según corresponda", y acto seguido en su artículo 28 se especifica, en cambio, que:

Podrá hacerse tratamiento de los datos personales de mayores de catorce y menores de dieciocho años con su consentimiento, siempre que la información proporcionada haya sido expresada en un lenguaje comprensible por ellos, salvo en los casos que la ley exija para su otorgamiento la asistencia de los titulares de la patria potestad o tutela (...).

Así, mientras en nuestro país persista la falta de pronunciamiento legal, consideramos que esta interpretación debiera ser el criterio imperante, es decir, distinguir con base en las categorías de niño, niña y adolescente establecidas por la Ley N ${ }^{\circ} 19.968$. Precisamente, además, ese es el criterio que aparece plasmado tanto en el Proyecto de Ley que regula la Protección y el Tratamiento de los Datos Personales y crea la Agencia de Protección de Datos (Boletín N . 11.144-07) ${ }^{74}$, como también en el Proyecto de Ley de Garantías y Protección Integral de los Derechos de la Niñez y la Adolescencia (Boletín N. ${ }^{\circ}$ 10.315-18).

Concretamente, el propio mensaje del primero de estos Proyectos de Ley se refiere explícitamente al tratamiento de datos personales de niños, niñas y adolescentes, señalando al efecto que este "sólo se puede realizar atendiendo al interés superior del niño/a y al respeto de

\footnotetext{
${ }^{73}$ Barcia (2013), p. 21.

${ }^{74}$ Este Proyecto de Ley que regula la protección y el tratamiento de los datos personales y crea la Agencia de Protección de Datos se encuentra hoy en día — abril de 2020 - en primer trámite constitucional en la Cámara del Senado.
} 
su autonomía progresiva”, por lo que en atención a tales consideraciones, el texto propone seguir las mejores prácticas de la legislación comparada y las recomendaciones internacionales, regulando en forma diferenciada las autorizaciones de tratamiento por un lado para niños y niñas, y por otro para adolescentes.

Por ello, en el artículo 16 quinquies del párrafo tercero del mismo Proyecto de Ley denominado "del tratamiento de categorías especiales de datos personales" se señala expresamente que:

Para tratar los datos personales de los niños y niñas se requiere el consentimiento otorgado en forma específica, expresa y previa por quien tiene a su cargo el cuidado personal, salvo que expresamente lo autorice o mandate la ley. Los datos personales de los adolescentes, salvo los datos personales sensibles, se pueden tratar de acuerdo con las normas de autorización previstas en esta ley para los adultos. Los datos personales sensibles de los adolescentes sólo se podrán tratar con el consentimiento otorgado en forma específica, expresa y previa por quien tiene a su cargo el cuidado personal, salvo que expresamente lo autorice o mandate la ley. Para los efectos de esta ley se consideran niños a los menores de catorce años, y adolescentes a los mayores de catorce y menores de dieciocho años.

Como se puede observar, el Proyecto sigue la tendencia internacional dando por fin regulación expresa al consentimiento de estos titulares justamente haciendo coincidir la diferenciación con el grado de autonomía que veníamos proponiendo, pero además por añadidura proporciona solución a una de las cuestiones planteadas anteriormente referida a la categoría especial de datos sensibles. Con respecto a estos, la normativa otorga una protección reforzada, estableciendo una excepción al otorgamiento de consentimiento autónomo por parte del adolescente, requiriendo la autorización en forma específica, previa y expresa por parte de quien tiene su cuidado personal. Es más, el Informe de la Comisión de Constitución, Legislación y Justicia recaído en el proyecto discutió la posibilidad de definir datos sensibles como: "todo dato personal cuyo tratamiento pueda dar origen a una discriminación arbitraria o ilegal o conlleve un grave riesgo para su titular, tales como datos de niños, niñas y adolescentes $(\ldots)^{75 "}$.

\subsection{PROYECTO DE LEY DE GARANTÍAS Y PROTECCIÓN INTEGRAL DE LOS DERECHOS DE LA NIÑEZ Y LAADOLESCENCIA}

Tal y como ya hemos apuntado en apartados anteriores del presente estudio, la vigente LPVP no contiene previsión específica alguna con respecto a niños, niñas y adolescentes. No obstante, y como recién analizamos en el precedente epígrafe, sí existe un Proyecto de Ley, en primer trámite constitucional, que vendría, en cierta medida, a dar respuesta a dichas falencias. Además,

75 Informe de la Comisión de Constitución, Legislación, Justicia y Reglamento (2018), p. 220. 
por si ello fuera poco, en el Proyecto de Ley de Garantías y Protección Integral de los Derechos de la Niñez y la Adolescencia (Boletín N. 10.315-18), en estado avanzado de tramitación en el Senado chileno, también se contiene regulación específica al respecto.

En este sentido, el artículo 31 del Proyecto de Ley de Garantías y Protección Integral de los Derechos de la Niñez y la Adolescencia, intitulado vida privada y protección de datos personales, reconoce expresamente, en su inciso segundo, el derecho de los niños, niñas y adolescentes a la protección de sus datos personales, así como a impedir el tratamiento o la cesión de estos, según lo establecido en la legislación vigente. Acto seguido, en su inciso tercero, el citado precepto prevé una presunción iuris tantum — que admite, por tanto, prueba en contrario- de madurez suficiente para otorgar el consentimiento prevenido en la LPVP —o cuerpo legal que venga a substituirlo- a los catorce años de edad, y no ostentarla, antagónicamente, inducirnos a pensar justamente lo contrario. En sí, este precepto formaliza tres reglas elementales. Primera, podrán ejercitar libremente los derechos reconocidos en la legislación protectora de la vida privada las personas menores de dieciocho años y mayores de catorce ${ }^{76}$. Esta acotación, no obstante, queda modulada por una segunda mención que obliga a contar con la asistencia de los padres y/o madres, representantes legales o personas que los tengan legalmente a su cuidado cuando la Ley así lo prevenga. Por último, se requerirá autorización de los representantes legales para proceder al tratamiento automatizado de los datos de personas menores de edad cuando éstas no hayan alcanzado aún la cifra de los catorce años de edad -en realidad se presumirá que no ostentan la madurez suficiente-. En este último caso, siempre deberá escucharse al niño o niña si tiene suficiente grado de madurez para ello ${ }^{77}$.

Finalmente, para concluir con el análisis de los aspectos más relevantes que nos ofrece el citado artículo 31 del Proyecto de Ley Garantías y Protección Integral de los Derechos de la Niñez y la Adolescencia, y abordando ahora la cuestión desde un punto de vista más funcional, los propósitos perseguidos por la norma con la introducción de un precepto del estilo del apuntado, se circunscriben, por lo que a la defensa de los derechos de los sujetos implicados se refiere,

\footnotetext{
${ }^{76}$ Bartolomé (2015), p. 286, si bien refiriéndose a la realidad española, realiza una reflexión que entendemos sería plenamente aplicable al artículo 31 del Proyecto de Ley de Garantías y Protección Integral de los Derechos de la Niñez y la Adolescencia, al constatar que debe conjugarse la edad, en tanto que presunción iuris tantum, con la capacidad natural y madurez, de la persona menor de edad, los elementos volitivos, reflexivos y emocionales, los derechos de la personalidad que estén en juego y cuál sería el papel de los responsables parentales.

77 El inciso tercero del artículo 31 del Proyecto de Ley de Garantías y Protección Integral de los Derechos de la Niñez y la Adolescencia establece que: "Se presumirá que toda persona mayor de catorce años tiene la capacidad suficiente para consentir por sí misma el tratamiento de sus datos de carácter personal, salvo que la ley exija para su prestación la asistencia de su padre y/o madre, representantes legales o persona que los tenga legalmente a su cuidado. En este último caso siempre deberá escucharse al niño, niña o adolescente si tiene suficiente grado de madurez".
} 
tanto a la protección directa de los niños, niñas y adolescentes como al de su inmediato entorno familiar. Ello nos explica por qué en su inciso cuarto, en aras a prevenir un uso instrumental de la persona menor de edad, veda la posibilidad de utilizarlo como fuente de captación de datos relativos a otros miembros de la familia, o sobre sus características identificadoras, como los datos relativos a la actividad profesional de los progenitores, información económica, indicadores sociológicos o cualesquiera otros, sin la autorización de sus titulares ${ }^{78}$.

Asimismo, se impone al encargado del fichero y responsable del tratamiento la obligación de informar a los niños, niñas y adolescentes, en un leguaje claro y fácilmente comprensible, de todos sus derechos y responsabilidades en torno a la protección de sus datos personales ${ }^{79}$. Parece lógico que, si un adolescente ha de prestar el consentimiento para el tratamiento de sus datos, primero debe conocer exactamente que está consintiendo, con lo que la información previa y detallada se convierte en una condición indispensable para el otorgamiento de una declaración de voluntad válida ${ }^{80}$.

\subsection{VERIFICACIÓN DEL CONSENTIMIENTO PRESTADO POR EL/LA ADOLESCENTE O POR LOS REPRESENTANTES LEGALES}

Tomando en consideración que el ámbito en que los y las adolescentes ceden sus datos mayoritariamente es internet, no queremos finalizar este estudio, sin antes reflexionar acerca del modo en que en dicho entorno digital los prestadores de servicios recaban el consentimiento de los usuarios al solicitarles determinados datos de carácter personal.

A nuestro parecer, resulta evidente que es el responsable del tratamiento el que tiene la carga de verificar que la declaración de voluntad digital fue válidamente emitida por el adolescente si contaba con catorce años de edad-o autorizada por sus representantes legales —en caso de tratarse de niños o niñas que no ostentan suficiente grado de madurez-81. Dichos responsables tienen libertad para desarrollar métodos que permitan cumplir con esa obligación adaptado a

\footnotetext{
${ }^{78}$ Establece el mentado inciso cuarto del artículo 31 del Proyecto de Ley de Garantías y Protección Integral de los Derechos de la Niñez y la Adolescencia que "en ningún caso podrán obtenerse del niño, niña o adolescente datos que permitan acceder a información sobre el resto de los miembros del grupo familiar, o sobre sus características, como las relativas a los datos profesionales del padre y/o madre, representantes legales o personas que los tengan legalmente a su cuidado, información económica, datos sociológicos o cualquiera del mismo estilo, sin el consentimiento de sus respectivos titulares".

${ }^{79}$ El inciso quinto del artículo 31 del Proyecto de Ley de Garantías y Protección Integral de los Derechos de la Niñez y la Adolescencia reza del siguiente tenor literal: "Cuando el tratamiento esté referido a datos de niños, niñas y adolescentes, la información dirigida a los mismos deberá expresarse en un lenguaje que sea fácilmente comprensible para aquellos".

${ }^{80}$ Martínez (2013), pp. 178-179.

${ }^{81}$ Brito (2018), p. 8.
} 
sus operaciones diarias. También debe garantizarse la posibilidad de retirar en cualquier momento la declaración de voluntad prestada y que sea tan fácil retirarla como lo fue darla.

Cuando se prestan servicios de la sociedad de la información a niños, niñas y adolescentes sobre la base del consentimiento, se espera que los responsables adopten todas las medidas razonables para verificar que el usuario supera la edad del consentimiento digital, y estas medidas deben ser proporcionales a la naturaleza y riesgos de las actividades de tratamiento.

Si los usuarios declaran que superan la edad de consentimiento digital, el responsable podrá llevar a cabo las comprobaciones necesarias para verificar que dicha declaración es cierta. En cambio, si la persona declara no haber alcanzado la edad necesaria para dar su consentimiento digital, entonces el responsable puede aceptar dicha declaración sin más comprobaciones, pero deberá entonces obtener la autorización de los progenitores y verificar que la persona que presta la declaración de voluntad es su representante legal.

La verificación de la edad no debe conducir a un tratamiento excesivo de datos. El mecanismo elegido para corroborar la edad del interesado/a debe conllevar una evaluación de los riesgos inherentes al tratamiento propuesto, así como de la tecnología disponible. En algunas situaciones de bajo riesgo, puede resultar adecuado solicitar a los nuevos subscriptores de un servicio que indiquen su año de nacimiento o completen un formulario en el que declaren que son (o no son) menores de edad. Por el contrario, en casos en los que el riesgo sea elevado, puede resultar adecuado pedir más pruebas, de manera que el responsable pueda verificar la persona o su representante legal (caso de no alcanzar la edad de consentimiento digital) ${ }^{82}$.

Este deber de verificación se configura, en definitiva, como una obligación de hacer, y no como una obligación de resultado. Efectivamente, el responsable del tratamiento cumplirá con su cometido desplegando la actividad diligente debida, con independencia de cuál sea el desenlace final. En suma, si el responsable del tratamiento logra demostrar que hizo "esfuerzos razonables" para llevar a cabo la recogida de dicho consentimiento digital, no se le podrá exigir responsabilidad alguna (por ejemplo, si la persona menor de edad adulteró su cédula de identidad o falsificó la firma de sus representantes legales y presentó sus credenciales sin su debido consentimiento) ${ }^{83}$.

${ }^{82}$ Hidalgo (2017), pp. 1-31.

${ }^{83}$ García (2018), p. 10. 
Ahora bien, el verdadero nudo gordiano radica en resolver la interrogante acerca de qué se entiende por "esfuerzos razonables", pues de ello dependerá que el consentimiento recabado sea o no válido. Esta cuestión parece no estar resuelta por la normativa europea, pues si bien es cierto, esta sí se pronuncia expresamente sobre quién recae la obligación de verificar la concurrencia efectiva del consentimiento, no estipula criterio, recomendación o pauta alguna sobre los mecanismos, procedimientos o métodos más adecuados a tal fin, rigiendo un principio de libertad de forma al respecto ${ }^{84}$. Y es en este contexto, en que puede afirmarse que la regulación norteamericana de protección en línea del derecho a la privacidad de las personas menores de edad, la conocida como Children's Online Privacy Protection Act de 1998 (COPPA), es pionera aportando ciertas luces sobre el particular (criterios de verificación del consentimiento paterno $)^{85}$, las cuales podrían inspirar el modo de resolver esta controversia por parte del legislador chileno ${ }^{86}$.

En este último punto, y ya para cerrar, resulta necesario y pertinente evidenciar, que no debe confundirse la cuestión de la capacidad para prestar el consentimiento digital, con las disposiciones generales del derecho patrimonial contractual. Por lo tanto, los requisitos de consentimiento válido para el uso de datos relativos a niños, niñas y adolescentes forman parte de un marco jurídico que debe considerarse independiente del derecho contractual nacional. Por ende, no entraremos a valorar la validez y/o eficacia de los contratos suscritos por una persona menor de edad en línea.

\section{Conclusiones}

La modernización del estatuto legal relativo a la protección de datos personales debe privilegiar la protección y defensa de los derechos de niños, niñas y adolescentes, y esto a

\footnotetext{
${ }^{84}$ Brito (2017), p. 7.

${ }^{85}$ Brito (2018), p. 9.

${ }^{86}$ La normativa norteamericana fija la capacidad de la persona menor de edad para consentir el tratamiento de sus datos personal es en trece años, pero establece una serie de mecanismos para verificar el cumplimiento de tal requisito, tanto en lo que se refiere al control de acceso de los niños, niñas y adolescentes, como en la obtención del consentimiento parental. En este último sentid o, plantea los siguientes criterios de verificación del consentimiento: proporcionar formularios de consentimiento a firmar por los representantes legales; facilitar un número telefónico gratuito o una video conferencia para que los representantes legales entren en contacto con el personal del responsable del tratamiento; enviar, con posteridad a la prestación del consentimiento, un mensaje por vía electrónica a los representantes legales para que confirmen su declaración de voluntad; comprobar la identidad de los representantes legales a través de bases de datos de identificación emitidas por el Gobierno; implantar un sistema de e-mail Plus o de doble verificación que permita solicitar que los representantes indiquen su consentimiento en un mensaje de retorno; y requerir al representante legal, en conexión con una transacción monetaria, el uso de una tarjeta de crédito, de débito u otro sistema de pago en línea que proporcione notificación de cada transacción discreta al titular de la cuenta principal.
} 
nuestro juicio impone la exigencia de apreciar adecuadamente su posición, la cual implica dar cabida a un ámbito de autonomía en el ejercicio del derecho.

Esto también significa que no basta con soluciones tecnológicas, sino que la mejor manera de garantizar social y jurídicamente la protección de la infancia y la adolescencia, y muy en particular en el mundo digital, es promover su autonomía como sujetos responsables en el ejercicio de sus derechos, y eso únicamente se logra formándolos como seres capaces, pensantes y con criterio para la toma de sus decisiones y la asunción de sus responsabilidades. Conseguir el acceso a las redes sociales sin que las personas menores de edad tengan suficiente madurez y conocimiento sobre las consecuencias que puede llegar a tener en su desarrollo integral, significa abrirles las puertas a una serie de relaciones sociales donde la técnica de comunicación empleada, sin contacto físico personal, es más proclive a crear espacios reservados de mayor complejidad en cuanto a su control. En este sentido, no se debe olvidar que el riesgo constituye un ingrediente no eliminable de las formas de vida de las sociedades tecnológicamente avanzadas, sin embargo, es innegable que los progresos de la era digital no son en sí mismos perjudiciales, sino que es su mal uso el que les otorga tal carácter, lo cual debiese impulsarnos a normar los nuevos comportamientos y relaciones que a su respecto pueden tener lugar.

\section{Bibliografía citada}

Acata Águila, Isaías (2011): “Internet, un derecho humano de cuarta generación”, en: Revista Misión Jurídica (volumen 4, número 4), pp. 37-58.

Aguilar Cavallo, Gonzalo (2010): “Derechos fundamentales-Derechos humanos. ¿Una distinción válida en el siglo XXI?", en: Boletín Mexicano de Derecho Comparado (número 127), pp. 15-57.

Aguirre, Alix y Manasía, Nelly (2015): “Derechos humanos de cuarta generación: inclusión social y democratización del conocimiento”, en: Télématique (volumen 14, núm. 1), pp. 216.

Aillapán Quinteros, Jorge Eduardo (2016): “El derecho a la propia imagen: ¿derecho personalísimo?, ¿derecho fundamental? Previsiones terminológicas para el ordenamiento jurídico chileno", en: Revista Chilena de Derecho (volumen 43, número 2), pp. 435-462. 
Álvarez Valenzuela, Daniel (2016): “Acceso a la información pública y protección de datos personales: ¿puede el Consejo para la Transparencia ser la autoridad central en materia de protección de datos?", en: Revista de Derecho Universidad Católica del Norte (año 23, número 1), pp. 51-79.

Andreu Martínez, María Belén (2013): La protección de datos personales de los menores de edad (Cizur Menor, Thomson Aranzadi).

Arén Vidal, Esther (2017): “El niño y las nuevas tecnologías: luces y sombras”, en: AEPap (ed.), Curso de actualización pediátrica (Madrid, Lúa ediciones), pp. 53-60.

Barcia Lehmann, Rodrigo (2013): “La capacidad extrapatrimonial de los niños y adolescentes conforme a sus condiciones de madurez", en: Revista Ius et Praxis (volumen 19, número 2), pp. 3-57.

Bartolomé Tutor, Aránzazu (2015): Los derechos de la personalidad del menor de edad. Su ejercicio en el ámbito sanitario y en las nuevas tecnologías de la información y comunicación (Cizur Menor, Thomson Reuters).

Bobbio, Norberto (1991): El tiempo de los derechos (Traducc. Rafael De Asís Roig, Madrid, Editorial Sistema).

Brito Izquierdo, Noemí (2018): “Tratamiento de los datos personales de menores de edad en la nueva normativa europea protectora de datos personales", en: Actualidad Civil (número 5), pp. 1-19.

(2017): "Tratamiento de los datos personales de menores de edad: supuestos, límites, retos y desafíos", en: La Ley Derecho de Familia (número 14), pp. 1-15.

Chaveli Donet, Eduard y Picazo Senti, Pedro (2003): “El tratamiento de datos de menores: la necesidad del consentimiento paterno", en: Revista Electrónica de Derecho Informático (número 56), pp. 1-18.

De la Parra Trujillo, Eduardo (2001): “Los derechos de la personalidad: teoría general y su distinción con los derechos humanos y las garantías individuales", en: Revista Jurídica Ibero (número 31), pp. 139-163. 
Del Río Sánchez, Olga (2009): “TIC, derechos humanos y desarrollo: nuevos escenarios de la comunicación social”, en: Anàlisi (año 2009, número 38), pp. 55-69.

Detrick, Sharon; Doeck, Jaap; y Cantwell, Nigell (1992): The United Nations Convention on the Right of the Child. A guide to the Traveaux Préparatoires (Dordrecht, Martinus Nijhoff Publishers).

Donoso, Lorena (2009): “El tratamiento de datos personales en el sector de la educación”, en: A.A.V.V., Chile y la protección de datos personales: ¿están en crisis nuestros derechos fundamentales? (Santiago, Ediciones Universidad Diego Portales) pp. 57-79.

Espejo Yaksic, Nicolás (2016): “El derecho a la vida familiar, los derechos del niño y la responsabilidad parental", en: A.A.V.V., Estudios de Derecho Familiar I (Santiago de Chile, Thomson Reuters), pp. 197-209.

Espejo Yaksic, Nicolás y Lathrop Gómez, Fabiola (2015): “Identidad de género, relaciones familiares y derechos de niños, niñas y adolescentes. Comentarios al proyecto de ley que reconoce y da protección al derecho a la identidad de género", en: Revista de Derecho Universidad Católica del Norte (volumen 22, número 2), pp. 393-418.

García Garnica, María del Carmen (2004): El ejercicio de los derechos de la personalidad del menor no emancipado (especial consideración al consentimiento a los actos médicos y a las intromisiones en el honor, la intimidad y la propia imagen) (Cizur Menor, Thomson Aranzadi).

García González, Aristeo (2007): “La protección de datos personales: derecho fundamental del siglo XXI. Un estudio comparado", en: Boletín Mexicano de Derecho Comparado (año XL, número 120), pp. 743-778.

García Herrera, Vanessa (2018): "El válido consentimiento para el tratamiento de los datos personales de los menores de edad en internet. Especial referencia al supuesto en que los representantes legales estén divorciados o separados", en: La Ley Derecho de Familia (número 20), pp. 1-14.

Garriga Domínguez, Ana (2016): “El origen doctrinal y jurisprudencial del derecho fundamental a la protección de datos personales como derecho diferente y autónomo del 
derecho a la intimidad", en: A.A.V.V., Nuevos Retos para la protección de datos personales en la era del Big Data y de la computación ubicua (Madrid, Editorial Dykinson), pp. 90-94.

Gil Antón, Ana María (2015): ¿Privacidad del menor en internet? (Cizur Menor, Thomson Aranzadi).

Godoy Domínguez, Luís (2018): "El conflicto entre el derecho a la intimidad de los menores en el uso de las TICs y el cumplimento de los deberes de la patria potestad", en: Actualidad Civil (número 12), pp. 1-22.

Guerrero Picó, María del Carmen (2006): El impacto de internet en el derecho fundamental a la protección de datos de carácter personal (Cizur Menor, Civitas).

Guzmán Brito, Alejandro (2006): Las cosas incorporales en la doctrina y en el derecho positivo (Santiago, Editorial Jurídica de Chile).

Heredero Higueras, Manuel (1997): La Directiva Comunitaria de Protección de Datos de Carácter Personal (Pamplona, Editorial Aranzadi).

Herrán Ortiz, Ana (2003): “El derecho a la protección de datos personales en la sociedad de la información”, en: Cuadernos Deusto de Derechos Humanos (año 2003, número 26), pp. 9-92.

Herrera Carpintero, Paloma (2016): "El derecho a la vida privada y las redes sociales en Chile", en: Revista chilena de Derecho y Tecnología (volumen 5, número 1), pp. 87-112.

Hidalgo Cerezo, Alberto (2017): “La protección de datos de los menores de edad. Especial referencia a sus excepciones en materia sanitaria y de educación”, en: La Ley. Derecho de Familia (número 15), pp. 1-31.

Jervis Ortiz, Paula (2002): “Derechos del titular de datos y habeas data en la Ley 19.628”, en: Revista chilena de Derecho informático (año 2002), pp. 19-33.

Lama Aymá, Alejandra (2006): La protección de los derechos de la personalidad del menor de edad (Valencia, Tirant lo Blanch).

Lathrop Gómez, Fabiola (2013): “El derecho a la imagen de niños, niñas y adolescentes en Chile. Una mirada crítica a la luz del Derecho Internacional de los Derechos Humanos y de los 
estatutos normativos iberoamericanos de protección integral de la infancia y de la adolescencia”, en: Revista chilena de Derecho (volumen 40, número 3), pp. 929-952.

(2017): “Derecho a la vida familiar, responsabilidad parental y derechos del niño, niña o adolescente", en: A.A.V.V. Estudios de Derecho de Familiar. Segundas Jornadas Nacionales de Derecho de Familia (Talca, Universidad de Talca), pp. 229-251.

Lorente López, María Cristina (2015): Los derechos al honor, a la intimidad personal y familiar y a la propia imagen del menor (Cizur Menor, Thomson Aranzadi).

Lovera Parmo, Domingo (2017): “Ciudadanía constitucional de niños, niñas y adolescentes”, en: A.A.V.V., Constitución política e infancia. Una mirada desde los derechos de los niños, niñas y adolescentes en Chile (Santiago de Chile, Unicef), pp. 149-184.

(2009a): “Libertad de expresión e interés superior del niño, a propósito de la Sentencia de la Corte de Apelaciones de Antofagasta de 6 de marzo de 2009 y Corte Suprema de 23 de abril de 2009”, en: Revista Chilena de Derecho Privado (número 12), pp. 215-225.

(2009b): “Niño, adolescente y derechos constitucionales: de la protección a la autonomía”, en: Justicia y Derechos del Niño (número 11), pp. 11-54.

Maqueo Ramírez, María; Moreno González, Jimena y Recio Gayo, Miguel (2017): “Protección de datos personales, privacidad y vida privada: la inquietante búsqueda de un equilibrio global necesario", en: Revista de Derecho, Valdivia (volumen 30, número 1), pp. 77-96.

Martínez Otero, Juan María (2013): La protección jurídica de los menores en el entorno audiovisual (Cizur Menor, Aranzadi).

Millaleo Hernández, Salvador (2015): “Los intermediarios de Internet como agentes normativos”, en: Revista de Derecho (volumen 28, número 1), pp. 33-54.

Morales Aguilera, Paulina (2016): “Los derechos humanos de cuarta generación desde la noopolítica", en: Derecho y Justicia (año 2016, número 7), pp. 39-66.

Morello, Augusto (1994): El proceso justo. Del garantismo formal a la tutela judicial efectiva de los derechos (La Plata, Editorial Abeledo-Perrot). 
Moreno Bobadilla, Ángela (2017): Intimidad y menores (Madrid, Centro de Estudios Políticos y Constitucionales).

Muñoz Massouh, Ana (2015): “Eliminación de datos personales en internet: El reconocimiento del derecho al olvido", en: Revista Chilena de Derecho y Tecnología (volumen 4, número 2), pp. 215-261.

Nieves Saldaña, María (2012): “The Right to Privacy: la génesis de la protección de la privacidad en el sistema constitucional norteamericano, el centenario legado de Warren y Brandeis", en: Revista de Derecho Político (año 2012, número 85), pp. 195-240.

Nogueira Alcalá, Humberto (2005): “Autodeterminación informativa y hábeas data en Chile e información comparativa", en: Anuario de Derecho Constitucional Latinoamericano (año 2005), pp. 449-471.

(2007): "El derecho a la propia imagen como derecho fundamental implícito. Fundamentación y caracterización", en: Revista Ius et Praxis (volumen 13, número 2), pp. 245-285.

(2019): “Consideraciones sobre la normativa constitucional acerca de derechos fundamentales y sus garantías en la perspectiva de reforma o cambio constitucional", en: A.A.V.V. Derechos para una nueva Constitución (Valencia, Tirant lo Blanch), pp. 39-84.

(2017): “La protección convencional de los derechos de los niños y los estándares de la Corte Interamericana de Derechos Humanos sobre medidas especiales de protección por parte de los Estados partes respecto de los niños, como fundamento para asegurar constitucionalmente los derechos de los niños y los adolescentes", en: Revista Ius et Praxis (volumen 23, número 2), pp. 415-462.

Orozco Pardo, Guillermo (2010): "Intimidad, privacidad, extimidad y protección de datos del menor ¿Un cambio de paradigma?”, en: Boix Reig, Javier, La protección jurídica de la intimidad (Madrid, Iustel), pp. 382-405.

Pérez Luño, Antonio Enrique (2013): “Las generaciones de derechos humanos”, en: Revista Direitos Emergentes Na Sociedade Global (volumen 2, número 1), pp. 163-196. 
Pizzorusso, Alessandro (2002): "Las generaciones de derechos”, en: Anuario de Derechos Humanos (año 2002, número 3), pp. 494-514.

Pulido Jiménez, Miguel (2011): “Convergencias y divergencias: acceso a la información y la tutela de los datos personales", en: A.A.V.V., Retos de la protección de datos personales en el sector público (Navarra, Editorial Aranzadi, SA), pp. 79-102.

Quezada Rodríguez, Flavio (2012): “La protección de datos personales en la jurisprudencia del Tribunal Constitucional de Chile", en: Revista chilena de Derecho y Tecnología (volumen 1, número 1), pp. 125-147.

Rabossi, Eduardo (1997): “Las generaciones de derechos humanos: la teoría y el cliché”, en: Revista Lecciones y Ensayos, Universidad de Buenos Aires (año 1997, números 69-71), pp. 4152.

Ravetllat Ballesté, Isaac (2017): “El consentimiento informado de la persona menor de edad a los tratamientos e intervenciones médicas", en: La Ley Derecho de Familia: Revista Jurídica sobre Derecho y Menores (número 13), pp. 20-44.

(2019): “El derecho de asociación de niñas, niños y adolescentes", en: A.A.V.V. Pensamiento jurídico central, Volumen II (Valencia, Tirant lo Blanch), pp. 235-257.

Reyes Méndez, Daniel (2019): “El acceso del menor a las redes sociales y el problema de su autentificación: la necesidad de una respuesta tecnológica", en: Diario La Ley (número 9335), pp. 1-10.

Riofrío Martínez, Juan Carlos (2014): "La cuarta ola de derechos humanos: los derechos digitales", en: Revista Latinoamericana de Derechos Humanos (Volumen 25, número 1), pp. $15-45$.

Rizik Mulet, Lucía (2019): "La responsabilidad parental y las nuevas tecnologías de la información y la comunicación", en: A.A.V.V. Estudios de Derecho de Familia IV (Santiago de Chile, Thomson Reuters), pp. 443-460.

Rogel Vide, Carlos (1985): Bienes de la personalidad, derechos fundamentales y libertades públicas (Bolonia, Publicaciones del Real Colegio de España en Bolonia). 
Santos Morón, María José (2011): “Menores y derechos de la personalidad. La autonomía del menor", en: A.A.V.V. El menor ante el derecho en el siglo XXI (Madrid, Anuario de la Facultad de Derecho de la Universidad Autónoma de Madrid), pp. 63-93.

Sanz Salguero, Francisco Javier (2017): “Grado de equivalencia entre la protección de los datos personales y el derecho de acceso a la información pública", en: Revista de Derecho de la Pontificia Universidad Católica de Valparaíso (volumen 48, número 1), pp. 135-163.

Schwabe, Jürgen (2009): Jurisprudencia del Tribunal Constitucional Federal Alemán. Extractos de las sentencias más relevantes compiladas por Jürgen Schwabe (Berlín, Konrad Adenauer Stiftung).

Troncoso Reigada, Antonio (2010): La protección de datos personales: En busca del equilibrio (Valencia, Editorial Tirant Lo Blanch).

Varas Braun, Juan Andrés (2010): “Decisiones vitales y representación parental: fundamento y límites", en: A.A.V.V. Estudios de Derecho Civil V (Santiago de Chile, Legal Publishing), pp. 337-356.

Valdés, Erick (2015): “Bioderecho, daño genético y derechos humanos de cuarta generación”, en: Boletín Mexicano de Derecho Comparado nueva serie (año XLVIII, número 144), pp. 1197 1228.

Vallespín Pérez, David (2002): El modelo constitucional de juicio justo en el ámbito del proceso civil (Barcelona, Editorial Atelier).

Vasak, Karel (1984): Las dimensiones internacionales de los derechos humanos (Barcelona, Serbal-Unesco), volumen I.

Villanueva Turnes, Alejandro (2017): "El derecho a la intimidad y el consentimiento de los menores de edad. Especial referencia a las redes sociales", en: Revista Boliviana de Derecho (número 23), pp. 208-221.

Warren, Samuel y Brandeis, Louis (1890): “The Right to Privacy”, en: Harvard Law Review (volumen 4, número 5), pp. 193-220.

Westin, Alan (1967): Privacy and freedom (New York, Atheneum Press). 
Zabía de la Mata, Juan (2008): “Artículo 13 del Reglamento 1720/2007, de 21 de diciembre”, en: A.A.V.V. Comentarios al Reglamento 1720/2007, de 21 de diciembre (Valladolid, Lex Nova), pp. 188-201.

\section{Normas jurídicas citadas}

Ley № 21.096, que consagra el Derecho a la Protección de Datos. Diario Oficial, 16 de junio de 2018.

Ley N¹9.628, sobre Protección de la Vida Privada. Diario Oficial, 28 de agosto de 1999.

Ley $\mathrm{N}^{\circ} 20.285$, sobre acceso a la información pública. Diario Oficial, 20 de agosto de 2008.

Reglamento (UE) 2016/679 del Parlamento Europeo y del Consejo de 27 de abril de 2016 relativo a la protección de las personas físicas en lo que respecta al tratamiento de datos personales y a la libre circulación de estos datos.

Proyecto de Ley de Garantías de los Derechos de la Niñez (Boletín N 10.315-18).

\section{Jurisprudencia citada}

Sentencia del Tribunal Constitucional Federal Alemán, BVG 209/85, de 15 de diciembre de 1983.

Sentencia del Tribunal Constitucional chileno, Rol $n^{\circ} 198-94$, dictada con fecha 4 de enero de 1995.

Sentencia del Tribunal Constitucional español, número 292/2000, de 30 de noviembre de 2000.

Sentencia del Tribunal de Justicia de la Unión Europea, C-362/12, de 6 octubre de 2015.

Sentencia del Tribunal Constitucional español, número 27/2020, de 24 de febrero de 2020. 